University of Montana

ScholarWorks at University of Montana

Graduate Student Theses, Dissertations, \&

Professional Papers

1972

\title{
Effects of protein deprivation on dominance measured by shock avoidance competition and food competition
}

Larry Andrew Wise

The University of Montana

Follow this and additional works at: https://scholarworks.umt.edu/etd

Let us know how access to this document benefits you.

\section{Recommended Citation}

Wise, Larry Andrew, "Effects of protein deprivation on dominance measured by shock avoidance competition and food competition" (1972). Graduate Student Theses, Dissertations, \& Professional Papers. 5635.

https://scholarworks.umt.edu/etd/5635

This Thesis is brought to you for free and open access by the Graduate School at ScholarWorks at University of Montana. It has been accepted for inclusion in Graduate Student Theses, Dissertations, \& Professional Papers by an authorized administrator of ScholarWorks at University of Montana. For more information, please contact

scholarworks@mso.umt.edu. 


\title{
THE EFFECTS OF PROTEIN DEPRIVATION ON DOMINANCE MEASURED BY SHOCK AVOIDANCE COMPETITION AND FOOD COMPETITION
}

\author{
By \\ Larry Wise \\ B.A., Central Washington State College, 1968 \\ Presented in partial fulfillment of the requirements for the degree of \\ Master of Arts \\ UNIVERSITY OF MONTANA \\ 1972
}

Approved by:

Qhetax R Zmmenom
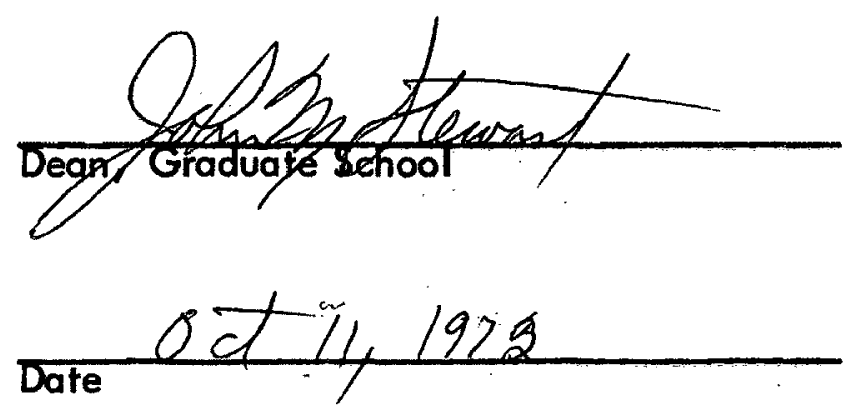
UMI Number: EP41099

All rights reserved

INFORMATION TO ALL USERS

The quality of this reproduction is dependent upon the quality of the copy submitted.

In the unlikely event that the author did not send a complete manuscript and there are missing pages, these will be noted. Also, if material had to be removed, a note will indicate the deletion.

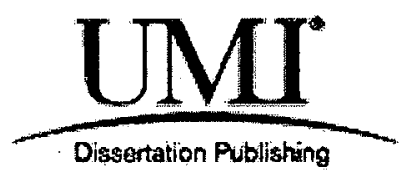

UMI EP41099

Published by ProQuest LLC (2014). Copyright in the Dissertation held by the Author.

Microform Edition (C ProQuest LLC.

All rights reserved. This work is protected against unauthorized copying under Title 17, United States Code

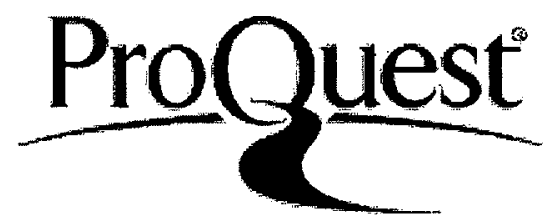

ProQuest LLC.

789 East Eisenhower Parkway

P.O. Box 1346

Ann Arbor, Ml $48106-1346$ 
$10-12,-72$

\section{ACKNOWLEDGMENTS}

The author gratefully acknowledges the helpful criticism given by his thes is committee: Dr. Robert Zimmermann, chairman; Dr. Andrew Lee; Dr. Laurence Berger; and Dr. Victor Duke. 


\section{TABLE OF CONTENTS}

Page

ACKNOWLEDGEMENTS .................. ii LIST OF TABLES ....................... iv

Chapter

1. INTRODUCTION .................... I

Field Studies .................. 1

Laboratory Investigations . . . . . . . . . . 2

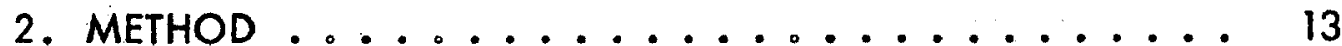

Subjects ...................... 13

Apparatus ................... 13

Design ..................... 16

Dominance Criteria ............... 17

Procedure ...................... 18

3. RESULTS ............................. 22

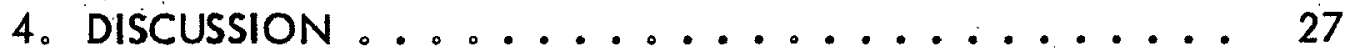

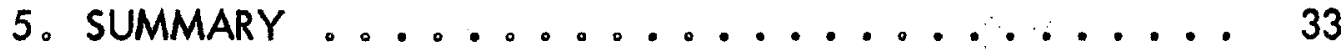

REFERENCES。........................ 34 


\section{LIST OF TABLES}

Table

Page

1. T-tests between age paired groups on social and food

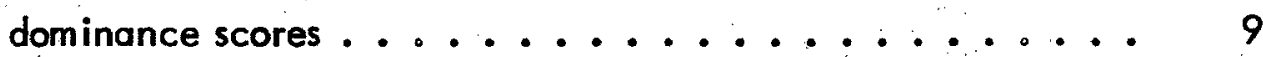

2. Correlations of dominance rankings on social interactions

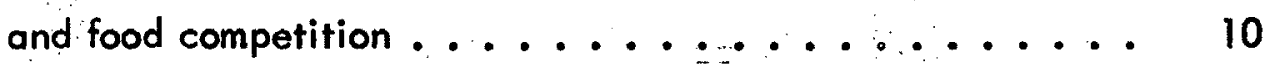

3. Subject and group discription ................ 14

4. Correlations between tests ................... 23

5. T-tests between groups III and IV on three measures of

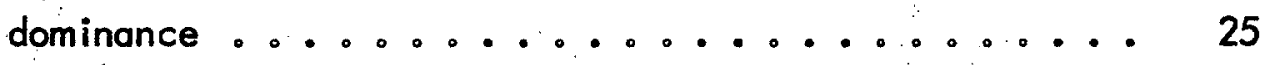

6. Within groups ranking on three measures of dominance . . . 26 


\section{Chapter 1}

\section{INTRODUCTION}

In the language of the layman, such terms as dominance and competition are considered to be clear cut common knowledge. The dominant animal is stronger, bigger, and more willing to fight; his dominance status is determined by abservation of his aggressive behavior. In the science of Psychology, the concept of dominance has been derived from field and laboratory observations as a description of a key function of group behavior. Field Studies

C. R. Carpenter (1963) gave a very inclusive definition of dominance as, "An individual is said to be dominant over another when it has priority in feeding, sexual, and locomotor behavior and when it is superior in aggressiveness and in group control to another or other individuals [p. 39]. " Masserman, Wechkin, and Woolf (1968) broke this construct of dominance down into two derivatives: basic rank (physical factors, i.e. weight and strength) and dependent rank (kinship relationships, see Koyama, 1967). Given these descriptive depictions of dominance, it is considered characteristic of primate groups that within a particular group relative individual dominance rankings are allotted to each group member (Carpenter, 1963).

The dominance status or rank ordering of individual monkeys within a social unit (group, troup, etc.) in field settings provides for social integration and group control in the natural environment (Carpenter, 1964). Disruptions of this dominance hierarchy lead to subsequent disruptions of the behavior of the group. Carpenter (1963) noted an example of this relationship when he removed the most dominant male rhesus (the alpha male) from a group of 85 wild monkeys 
and observed a considerable reduction in the territorial range of that group.

Communication of the individual's social status appears to be related by means of facial displays (Van Hooff, 1962). Van Hooff (1969) gave a rather precise description of the vocalization and locomotor tendencies which accompany these facial displays. Sparks (1969) pointed out that dominance status sets the occasion for social contact in the form of allogrooming which can take place following an appeasement "presentation" (Wickler, 1969) of a subordinate monkey in the proximity of a higher ranking individual. As Koford (1963) pointed out with rhesus colonies, most antagonistic disputes are resolved by means of signal exchanges which relate each individual's status in the immediate situation and usually result in confrontations without physical conflict.

Almann (1962) suggested that dominance relations among rhesus troups may depend on factors possibly involving learning, over and above relative fighting abilities, such as, the diversion of aggression, the forming of coalitions to ward off aggressors, and the ability to predict the behovior of other members of the group. Altmann also pointed out a close correlation between access to receptive oestrus females and dominance rank of the male. He observed in this relatively stable dominance hierarchy of the rhesus macaque that the status of an oestrous female will temporarily rise to that of her male consort for this short period of sexual activity. Laboratory Investigations

One of the first laboratory investigations of dominance among nonhuman primates was reported by Maslow and Flanzbaum in 1936. They employed two criteria of dominance. The first was a behavioral observation technique of recording paired animals' behaviors and matching these observations with agreed upon descriptions of dominance and subordinance. Secondly and most important, 
they adopted a competitive food situation wherein the dominant member of a pair of monkeys was defined as that animal recovering more food than the other. Food was delivered to the pair by means of a food chute in such a way that both animals had an equal opportunity to claim and eat it. Maslow (1936) suggested in a following experiment that dominance relations among rhesus macaques are quickly established and highly stable. He also pointed out that there was a general trend for the largest animals to be the most dominant and given situations of food deprivation the dominance roles were more sharply defined between individual animals.

An increasing number of investigators have employed the use of a competitive food situation between pairs of monkeys as a laboratory measure of dominance (Biernoff, Leary \& Littman, 1964; Hamilton, 1960; Leary \& Maroney, 1962; Maroney \& Leary, 1957; Maslow, 1936; Maslow \& Flanzbaum, 1936; Mason, 1960; Masserman et al., 1968; Miller \& Murphy, 1958; Miller, Murphy \& Mirsky, 1955; Murphy \& Miller, 1956; Nowlis, 1941, 1942; Plotnik, King \& Roberts, 1968; Warren \& Maroney, 1958). Most of these investigators in using a competitive food situation have adapted a standardized testing apparatus, the Wisconsin General Test Apparatus (WGTA) as the basic testing equipment for dominance measures. Usually raisins have been the incentives and rhesus macaques the subjects for ten trials per pair per day.

Objections to this type of competition were raised by Schusterman (1964) who indicated that competition was over when the food was eaten. He tested dominance with a manipulatory incentive in the form of different lengths of rope placed in a cage containing two paired monkeys. The measure of dominance was the amount of time each animal was in contact with the rope during a five minute period. He found that with the manipulatory incentive, a persistent 
competition situation was formed. This situation differed from the former in that between trials the pairs displayed more aggression, less grooming, and less play behavior.

A variety of variables have been investigated in relation to their effect on dominance in non-human primates; among these are social experience, environmental situation, sex, weight, deprivation, and artificial manipulations. Experimental investigation of these variables is examined in the following paragraphs.

In attempting to determine the effects of social experience on dominance behaviors, Angermeier, Phelps, Oreste, David and Reynolds (1967) set up four rearing conditions for 28 male rhesus macaques. These conditions consisted of: 1. Strict isolation (SI) --- no visual or tactual contact between individuals; 2 . Partial isolation (PI) --- some visual and moderate tactual contact between cage neighbors; 3. Social (S) --- two animals per cage and visual and tactual contact between cages; and 4. Enriched social (ES) --- same as (5) plus play objects, swings and televisions. Conclusions from this study were that the Partial isolation group tended to be heavier and have higher dominance ratings than the other three groups. However, they did suggest that visual and tactual experience are important factors in establishing dominance hierarchies. In another study it was stated that differential early rearing has no effect upon later dominance status, and that what is important in the formation of a new hierarchy was the individual monkey's previously achieved dominance status (Angermeier \& Phelps, 1967).

In a somewhat different manipulation of social experience, Mason (1960) compared the descriptive dominance behavior of a feral group and a socially restricted group (no physical contact between individuals). The restricted group was developmentally retarded in behavioral patterns of aggression, grooming, and 
sexual responses. Mason (1961), continuing this feral and restricted comparison, hypothesized that learning was the key factor in the differences found in the effectiveness of the dominance displays of the two groups. In the feral group aggression was limited to the dominant animal, but in the restricted group the opposite was true with the subordinates initiating most of the aggressive actions. In actual food competition, reversals between sessions were quite frequent for the restricted group whereas the feral group formed a stable dominance hierarchy that held throughout the study. The ability of the feral group to communicate status, apparently a learning dependent behavior, aided in establishing an effective dominance hierarchy.

In considering the individual animal's physical characteristics, Warren and Maroney (1958) found that weight, sex, and level of spontaneous activity were not significantly related to dominance in a WGTA competitive situation. Angermeier, Phelps, Murray, and Reynolds (1967), however, reported that weight differences between groups did effect the dominance ratings. In two other studies (Angermeier, Phelps, Murray, \& Howansteine, 1968; Angermeier, Phelps, Oreste, Davis \& Reynolds, 1967) weight had little or no effect on the outcome of the dominance tests except for the qualification given by Angermeier ef al. (1968) that a weight difference of 1,000 grams or more was necessary for weight to be a factor in dominance measures.

In regard to the sex of the individual, Angermeier et al. (1968) suggested that different behavioral patterns are involved in the female as compared to the male rhesus in the dominance situation. They observed less aggression and fighting among females and more avoidance of the dominant member by the subordinate female than was seen with males. Also, Nowlis (1942) using female chimpanzees found that they scored higher in dominance tests during maximum genital swelling 
than in the residual phase of their menstrual cycle.

Warren and Maroney (1958) demonstrated that neither the quantity of the incentive nor the fact that the dominant animal was pre-fed affected the competition in the WGTA situation. However, they did discover that on a low preference incentive (mashed eggs) when compared with more preferred foods (potatoes or raisins) subordinates were more successful in competition. Warren and Maroney's (1958) results conflict somewhat with Nowlis's (1942) finding that when subordinates were deprived and the dominant member was not deprived, scores for the subordinant increased in food competition. When both animals, dominant and subordinate, are at the same degree of deprivation, the dominance relation does, however, remain stable (Nowlis, 1941). Boelkins (1967) claimed that a good measure of dominance in a home cage group situation is the elapsed time from water onset until each animal drank for at least a period of 20 seconds following water deprivation for the entire group. Elaboration on water deprivation and dominance has not been followed up as yet.

Dominance reversals were found (Leary \& Maroney, 1962) when animals were tested in their home cages, alternately one animal being a "host" and the other a "guest." Hosts tended to obtain more food in competition than guests, and in one week's time when tested in a neutral WGTA on the same criterion of dominance, reversals still held. In a similar study (Masserman et all., 1968) dominance status of subordinates was raised when three animals were cagemates (subordinates being cagemates) and the fourth was a stranger as compared to four noncagemates. Failures to alter dominance were recorded (Maroney \& Leary, 1957; Maroney, Warren, \& Sinha, 1959) when young rhesus monkeys were given conditioning experience of either failure or success in the competitive situation by selective pairings and then later tested with their controls. The 
evidence suggested that conditioning did not generalize with monkeys as it has with mice in competition situations (Ginsberg \& Allee, 1942) apparently because monkeys can differentiate between individuals more accurately.

In manipulating dominance by pairing shock with the presentation of a subordinate partner (CS for shock), Miller et al : (1955) and Murphy and Miller (1956) found that dominance scores reversed for those individuals conditioned; and the scores for the stimulus animal (CS) also increased with animals not conditioned by shock pairings. Murphy and Miller (1956) indicated that, "The modification of dominance provides behavioral evidence for the presence of fear in avoidance learning which is independent of the conditioning situation [p. 247]."

In general an animal dominant in one situation will be dominant in another situation given a similar criterion of dominance (Biernoff et al., 1964), and these dominance measures will be stable over an extended period of time (Miller \& Murphy, 1956). Turning from an appetitive measurement of dominance, Miller and Banks (1962) measured dominance by shock avoidance in a situation where only one member of a pair (the dominant member) could successfully avoid or escape electrical shock by sitting on a small perch. Miller and Banks (1962) pointed out that advantages of this measure of dominance are as follows: 1. shock is an effective motivation for all animals whereas food sometimes is not, and 2 . distractions and nonrelevant interactions are minimized with shock but not with food competition.

Two studies comparing the methods of shock avoidance and food competition as measures of dominance produced opposite results. Plotnik et al. (1968) found less decisiveness with shock avoidance than food competition with squirrel and cebus monkeys. However, Hamilton (1960) found dominance hierarchies 
as determined by food competition to be very similar to dominance hierarchies determined by shock avoidance competition using rhesus macaques. The differences between these two studies may be in the social behavior of the different species (squirrel and cebus versus rhesus monkeys) with the rhesus having much more observed and experimentally recorded dominance behavior.

Field observations listed above have demonstrated that dominance is found to be a behavioral element of non-human primate social relationships. Dominance has been experimentally measured by means of competitive situations in the laboratory. Differences in the social behavior of manipulated groups of rhesus macaques (see Mason, 1960, 1961) can be meaningfully determined by measurements of the dominance relationships of these groups.

Factors that effect dominance are important in understanding the functional social situation. Results of a pilot study with rhesus macaques demonstrated on initial examination that such factors could be linked to protein deprivation of the animal. Also, the measurement of dominance under this condition of protein deprivation varies depending upon the type of measurement technique. The results of this pilot study are found in Tables 1 and 2 .

Two measures of dominance were used in this pilot study. The first was a measure of social interaction based on a technique by Locke, Morgan, and Zimmermann (1964) and Locke, Locke, Morgan, and Zimmermann (1964) where dominant/aggressi ve interactions are numerically recorded in a social playroom. The other measure was basically food competition in the same sacial playroom with one piece of food per trial for 20 trials per test pair. The results strongly indicate a definite difference in dominance between the low and high protein rhesus for social interaction 'with the high protein animals being much more dominant. In the food competition situation there was no significant difference 
Table 1

t-Tests Between Age Paired Groups on

Social and Food Dominance Scores

\begin{tabular}{|c|c|c|c|}
\hline Animal & $\begin{array}{l}\text { Group \& Age in days } \\
\text { when diet started }\end{array}$ & Social Dominance & Food Competition \\
\hline $\begin{array}{l}3508 \\
3509 \\
4303 \\
4310\end{array}$ & $\begin{array}{l}\text { age control } \\
\text { age control } \\
\text { age control } \\
\text { age control }\end{array}$ & $\begin{array}{r}103.9 \\
53.2 \\
101.5 \\
145.1\end{array}$ & $\begin{array}{l}15.3 \\
8.45 \\
7.65 \\
4.75\end{array}$ \\
\hline $\begin{array}{l}1 \\
2 \\
3 \\
4\end{array}$ & $\begin{array}{l}380 \text {-low protein } \\
380 \text {-low protein } \\
380 \text {-low protein } \\
380 \text {-low protein }\end{array}$ & $\begin{array}{c}24.1 \\
16.8 \\
28.4 \\
1.6 \\
T=4.224^{*} \mathrm{df}=6\end{array}$ & $\begin{array}{c}14.6 \\
14.2 \\
1.9 \\
11.85 \\
T=.43 \mathrm{df}=6\end{array}$ \\
\hline $\begin{array}{r}5 \\
6 \\
5766 \\
5872 \\
5976 \\
5979\end{array}$ & $\begin{array}{l}210 \text {-low protein } \\
210-\text { low protein } \\
210 \text {-low protein } \\
210 \text {-low protein } \\
210 \text {-low protein } \\
212 \text {-low protein }\end{array}$ & $\begin{array}{r}3.0 \\
2.2 \\
2.2 \\
10.5 \\
16.4 \\
18.8\end{array}$ & $\begin{array}{c}4.85 \\
11.1 \\
12.3 \\
13.1 \\
5.4 \\
9.2\end{array}$ \\
\hline $\begin{array}{l}5754 \\
5755 \\
5756 \\
5758\end{array}$ & $\begin{array}{l}\text { 210-high protein } \\
210 \text {-high protein } \\
210 \text {-high protein } \\
210 \text {-high protein }\end{array}$ & $\begin{array}{c}21.4 \\
154.5 \\
137.2 \\
158.9 \\
T=4.196^{*} \quad d f=8\end{array}$ & $\begin{array}{c}11.27 \\
11.03 \\
7.47 \\
12.97 \\
T=.675 \mathrm{df}=8\end{array}$ \\
\hline $\begin{array}{r}8 \\
9 \\
10 \\
13\end{array}$ & $\begin{array}{l}\text { 120-low protein } \\
120 \text {-low protein } \\
120 \text {-low protein } \\
120 \text {-low protein }\end{array}$ & $\begin{array}{r}93.0 \\
166.6 \\
11.8 \\
65.9\end{array}$ & $\begin{array}{l}14.25 \\
14.8 \\
15.8 \\
11.45\end{array}$ \\
\hline $\begin{array}{l}15 \\
16 \\
17 \\
18\end{array}$ & $\begin{array}{l}\text { 120-high protein } \\
\text { 120-high protein } \\
\text { 120-high protein } \\
120 \text {-high protein }\end{array}$ & $\begin{array}{c}50.5 \\
58.6 \\
24.9 \\
47.4 \\
T=1.181 . \mathrm{df}=6\end{array}$ & $\begin{array}{c}2.85 \\
3.5 \\
3.8 \\
13.5 \\
T=3.019 * * . \mathrm{df}=6\end{array}$ \\
\hline
\end{tabular}


Table 2

Correlations of Dominance Rankings on Social

Interactions and Food Competition

\begin{tabular}{|c|c|c|c|c|}
\hline Animal & Group & Social Rank & Food Rank & Correlations \\
\hline $\begin{array}{l}3508 \\
3509 \\
4303 \\
4310\end{array}$ & $\begin{array}{l}\text { age control } \\
\text { age control } \\
\text { age control } \\
\text { age control }\end{array}$ & $\begin{array}{l}3 \\
4 \\
1 \\
2\end{array}$ & $\begin{array}{l}1 \\
4 \\
3 \\
2\end{array}$ & $\begin{array}{l}r=.2 \\
T=.288 \\
d f=2\end{array}$ \\
\hline $\begin{array}{l}1 \\
2 \\
3 \\
4\end{array}$ & $\begin{array}{l}380 \text {-low protein } \\
380 \text {-low protein } \\
380 \text {-low protein } \\
380 \text {-low protein }\end{array}$ & $\begin{array}{l}3 \\
2 \\
1 \\
4\end{array}$ & $\begin{array}{l}1 \\
2 \\
4 \\
3\end{array}$ & $\begin{array}{l}r=.4 \\
T=.617 \\
d f=2\end{array}$ \\
\hline $\begin{array}{r}5 \\
6 \\
5766 \\
5872 \\
5976 \\
5979\end{array}$ & $\begin{array}{l}210 \text {-low protein } \\
210 \text {-low protein } \\
210 \text {-low protein } \\
210 \text {-low protein } \\
210 \text {-low protein } \\
210 \text {-low protein }\end{array}$ & $\begin{array}{l}4 \\
6 \\
5 \\
2 \\
1 \\
3\end{array}$ & $\begin{array}{l}2 \\
3 \\
5 \\
1 \\
4 \\
6\end{array}$ & $\begin{array}{l}r=.085 \\
T=.172 \\
d f=4\end{array}$ \\
\hline $\begin{array}{l}5754 \\
5755 \\
5756 \\
5758\end{array}$ & $\begin{array}{l}\text { 210-high protein } \\
210 \text {-high protein } \\
210 \text {-high protein } \\
210 \text {-high protein }\end{array}$ & $\begin{array}{l}4 \\
2 \\
3 \\
1\end{array}$ & $\begin{array}{l}1 \\
2 \\
4 \\
3\end{array}$ & $\begin{array}{l}r=-.4 \\
T=.617 \\
d f=2\end{array}$ \\
\hline $\begin{array}{r}8 \\
9 \\
10 \\
13\end{array}$ & $\begin{array}{l}\text { 120-low protein } \\
120 \text {-low protein } \\
120 \text {-low protein } \\
120 \text {-low protein }\end{array}$ & $\begin{array}{l}2 \\
1 \\
3 \\
4\end{array}$ & $\begin{array}{l}1 \\
2 \\
3 \\
4\end{array}$ & $\begin{array}{l}r=.8 \\
T=1.885 \\
d f=2\end{array}$ \\
\hline $\begin{array}{l}15 \\
16 \\
17 \\
18\end{array}$ & $\begin{array}{l}\text { 120-high protein } \\
\text { 120-high protein } \\
120 \text {-high protein } \\
120 \text {-high protein }\end{array}$ & $\begin{array}{l}3 \\
1 \\
4 \\
2\end{array}$ & $\begin{array}{l}4 \\
2 \\
3 \\
1\end{array}$ & $\begin{array}{l}r=.6 \\
T=1.06 \\
d f=2\end{array}$ \\
\hline
\end{tabular}


for two age groups. There was a significant difference in the third age group with the low protein animals obtaining higher dominance ratings than the high protein animals: Comparisons within groups across the two different measures demonstrated a negative correlation of -.4 for the 210 day high protein group. The 120 day low protein group had a correlation of .8 between social rank and food rank measurements. Also, the 120 day high protein group had a .6 correlation between the two measures of social status. The remaining three groups showed low correlations between the two measures of social rank which are found on Table 2.

The results of the pilot study demonstrate that high protein reared rhesus monkeys are rated higher in social dominance observation in a social room situation than low protein reared. However, there is a reversal of this dominance ranking when a competitive food technique is used. In food competition situations the low protein animals of all three age groups out-compete the high protein animals. In one case (120 low protein versus 120 high protein) there is a significant difference between these two groups with the low protein animals outcompeting the high protein animals. The reversals of dominance rating between the social situation and the food competition situation appear to be related to the fact that the low protein animals may be socially withdrawn but will become increasingly aggressive when food is presented.

On the basis of the above results it is hypothesized that:

1. Protein deprived rhesus macaques will be more dominant on the average than high protein macaques when compared on a food competition situation.

II. Protein deprived rhesus macaques will not be 
more dominant on the average than high protein macaques when compared on a nonappetitive competition situation, namely that of shock avoidance competition.

III. For rhesus macaques raised on high protein dominance measured by means of electrical shock avoidance competition will provide a stable and predictive dominance criterion which will correlate highly with dominance as measured by food competition. 
Chapter 2

\section{METHOD}

Subjects

Eighteen rhesus monkeys (Macaca mulatta) were used as subjects (the same animals used in the pilot study, see Tables 1 and 2). The subjects were put into two high protein diet groups and two low protein diet groups as listed in Table 3 . Group I has six animals, five females and one male, and was started on a low protein diet at 210 days of age. Group II has three males and one female, and was started on a high protein diet at 210 days of age. Group III has two males and two females, and was started on a low protein diet at 180 days of age. Group IV has three females and one male, and was started on a high protein diet at 120 days of age.

All animals were separated from their mothers at 90 days of age and maintained on a purified diet that was isocaloric and either contained $3 \%$ protein or $25 \%$ protein by weight. The $S_{s}$ were placed on their diet according to the schedule outlined in Table 3. All Ss of both high protein groups were maintained on one half their normal daily allotments of food throughout this experiment.

Apparatus

For the first appetitive measure of dominance a standard adult-sized Wisconsin General Test Apparatus (WGTA) was used. For a general description of the WGTA apparatus and its functioning consult Meyer, Treichler, and Meyer (1965). The particular WGTA used in this experiment was on a stand $67.3 \mathrm{~cm}$ off the floor. The stimulus tray was $44.45 \mathrm{~cm}$ wide and $24.13 \mathrm{~cm}$ long standing $5.08 \mathrm{~cm}$ in height mounted on wheels. The box containing the 
Table 3

Subject and Group Description

\begin{tabular}{|c|c|c|c|c|c|}
\hline Groups & Subjects & Sex & $\begin{array}{l}\text { Day of Age } \\
\text { Diet Started }\end{array}$ & Birth Date & $\begin{array}{l}\text { Response } \\
\text { Shock Level }\end{array}$ \\
\hline \multicolumn{6}{|l|}{ Group 1 . } \\
\hline $\begin{array}{l}\text { low protein } \\
\text { low protein } \\
\text { low protein } \\
\text { low protein } \\
\text { low protein } \\
\text { low protein }\end{array}$ & $\begin{array}{r}5 \\
6 \\
5766 \\
5872 \\
5976 \\
5979\end{array}$ & $\begin{array}{l}f \\
m \\
f \\
f \\
f \\
f\end{array}$ & $\begin{array}{l}210 \\
210 \\
210 \\
210 \\
210 \\
210\end{array}$ & $\begin{array}{l}7 / 01 / 68 \\
7 / 31 / 68 \\
6 / 10 / 68 \\
6 / 29 / 68 \\
6 / 30 / 68 \\
7 / 04 / 68\end{array}$ & $\begin{array}{l}.3^{* *} \\
.2 \\
.13 \\
.6 \\
.4 \\
.5\end{array}$ \\
\hline \multicolumn{6}{|l|}{ Group II } \\
\hline $\begin{array}{l}\text { high protein } \\
\text { high protein } \\
\text { high protein } \\
\text { high protein }\end{array}$ & $\begin{array}{l}5754 \\
5755 \\
5756 \\
3508^{*}\end{array}$ & $\begin{array}{l}m \\
m \\
f \\
m\end{array}$ & $\begin{array}{l}210 \\
210 \\
210 \\
-\end{array}$ & $\begin{array}{l}5 / 12 / 68 \\
5 / 13 / 68 \\
5 / 13 / 68 \\
9 / 25 / 67\end{array}$ & $\begin{array}{r}.5 \\
.8 \\
.3 \\
1.6\end{array}$ \\
\hline \multicolumn{6}{|l|}{ Group III } \\
\hline $\begin{array}{l}\text { low protein } \\
\text { low protein } \\
\text { low protein } \\
\text { low protein }\end{array}$ & $\begin{array}{r}8 \\
9 \\
10 \\
13\end{array}$ & $\begin{array}{l}m \\
f \\
f \\
m\end{array}$ & $\begin{array}{l}120 \\
120 \\
120 \\
120\end{array}$ & $\begin{array}{c}11 / 21 / 68 \\
11 / 17 / 68 \\
4 / 03 / 69 \\
5 / 27 / 69\end{array}$ & $\begin{array}{l}.3 \\
.5 \\
.4 \\
.25\end{array}$ \\
\hline \multicolumn{6}{|l|}{ Group IV } \\
\hline $\begin{array}{l}\text { high protein } \\
\text { high protein } \\
\text { high protein } \\
\text { high protein }\end{array}$ & $\begin{array}{l}15 \\
16 \\
17 \\
18\end{array}$ & $\begin{array}{l}f \\
f \\
f \\
m\end{array}$ & $\begin{array}{l}120 \\
120 \\
120 \\
120\end{array}$ & $\begin{array}{l}2 / 21 / 70 \\
3 / 16 / 70 \\
4 / 13 / 70 \\
4 / 14 / 70\end{array}$ & $\begin{array}{l}1.3 \\
.4 \\
.4 \\
.4\end{array}$ \\
\hline
\end{tabular}

* \#308 was added to Group II prior to the experiment to replace 5758 , who died of an impacted bowel.

** Shock intensity was measured in milliamperes. 
stimulus tray was $62.23 \mathrm{~cm}$ wide and $71.12 \mathrm{~cm}$ long. The cage containing the subject, located adjacent to the stimulus tray box, was $55.88 \mathrm{~cm}$ wide and 55.88 $\mathrm{cm}$ long. The floor of the cage was $53.34 \mathrm{~cm}$ off the floor. The stimulus tray box was illuminated from the ceiling with a florescent light and the opening between the stimulus tray box and the cage was closed off with a plexiglas guillotine door. The food incentive used on each trial was a single sugar coated piece of cereal ("Froot Loop").

For the second appetitive measure of dominance, a specially constructed two-cage food competition apparatus was designed to prevent actual body contact between test animals. This measurement technique will be called the parallel box competition (PBC). In the PBC apparatus each cage was $40.64 \mathrm{~cm}$ high, $41.91 \mathrm{~cm}$ wide, and $43.18 \mathrm{~cm}$ long, and was constructed of expanded metal and metal rods. The two cages were fixed in location $17.18 \mathrm{~cm}$ apart, facing each other. Between the two cages on a wooden track, a food delivery tray $(17.78$ $\mathrm{cm}$ wide and $22.86 \mathrm{~cm}$ long) slid between the two animals in the opposing cages. The food delivery tray was constructed such that the food placed in it was visible to the $\underline{S_{s}}$ but the $\underline{S}$ were prevented from reaching for it until two adjacent quillotine plexiglass partitions were raised simultaneously by $\underline{E}$ at the appropriate time. The cages were located $50.8 \mathrm{~cm}$ off the ground on an angle-iron frame, and the sides of the cages facing each other had the plexiglas guillotine partition flush against the individual cages leaving the appropriate space for the food tray in between the cages. The food used for the competition situation in this apparatus was the same as for the WGTA competition.

For shock avoidance competition two Grason-Stadler shock generators were used with scrambled shock presented separately to the opposite sides of a shuttle box. The apparatus consisted of a grey shuttle box divided in half by a 
barrier of metal rods and wood paneling. The shuttle box was $63.5 \mathrm{~cm}$ deep, $45.72 \mathrm{~cm}$ wide, and $55.245 \mathrm{~cm}$ between the barrier in the middle and the guillotine doors on each end. The guillotine doors were $27.94 \mathrm{~cm}$ up from the metal rod floor and $22.86 \mathrm{~cm}$ wide and centered at each end of the shuttle box.

The barrier in the center of the shuttle box consisted of a wall of metal rods $35.56 \mathrm{~cm}$ up from the metal rod floor met half way with wood paneling containing a size adjustable inverted U-shaped slot in the center of the barrier. This U-shaped slot provided the hole through which $\underline{S}$ could move from one side of the shuttle box to the other side; it also was closed by means of a guillotine door. The maximum opening of the hole was $19.05 \mathrm{~cm}$ wide and $16.51 \mathrm{~cm}$ high at the top of the inverted $U$. The shuttle box also had a small, $6.35 \mathrm{~cm}$ by 10.795 $\mathrm{cm}$ window located in the top center of each side of the box. On one side two lights were mounted covering the window so as to permit the $\underline{S}$ inside this side of the shuttle box to see either a red or green light. The side of the box containing the two lights was the start box since all Ss were started from this location. The opposite side of the shuttle box was an alleyway, and from it the $\underline{S}$ could go into a standard transportation cage placed on a platform adjacent to the exterior guillotine door. This transportation. cage will be called the goal box. The entrance to the goal box also had an adjustable opening with a maximum size of $22.86 \mathrm{~cm}$ by $27.94 \mathrm{~cm}$. The underside of the shuttle box was illuminated by a 100 watt bulb.

Design

The two main groups of $\underline{S}$ were on low and high protein diets with subgroups determined by the age of the Ss when the diet was started. All of the high protein animals were maintained on one half of their normal amount of daily food throughout the appetitive portions of this experiment. Dominance 
was measured by the successful avoidance of shock in a competition situation where only one animal of a pair could avoid the shock. Dominance was also measured on two food competition situations where only one piece of food was available per trial. An animal was considered dominant if it avoided the shock successfully on a majority (over half) of the trials per pairing. In the food competition situations an animal was considered dominant if it successfully obtained more than half of the pieces of food. Dominance scores were obtained within groups for all groups and between groups for groups III and IV.

All Ss were shaped individually to avoid shock by moving from the start box to the goal box within eight seconds, and they were considered shaped after completing two consecutive days of $100 \%$ avoidance for ten trial per day. Ss were shaped to remove food from the food competition apparatuses and allowed time to familiarize themselves with the new cages individually. Ss were considered shaped if they removed all ten pieces of food for two consecutive days. Dominance Criteria

With regard to dominance scoring, the most dominant animal (S meeting the dominance criterion the most times in the total number of pairings) was designated with a score of 1 , the second most dominant animal received a score of 2 , and so on down to the last animal rated. If two animals tied on the number of times they met the dominance criterion, then the more dominant animal of the two was the $S$ meeting the dominance criterion in their specific pairing. If this pairing was alos a tie, then the $\underline{\mathbf{S}}$ with the higher mean per cent food retrial (mean per cent successful avoidance for avoidance competition) was rated as most dominant: If the above procedure did not discriminate the dominant of the pair, then both the Ss were given the same over-all dominance ranking. This ranking was done for both avoidance competition and food competition. 


\section{Procedure}

All animals were tested on the three different competitive situations in the following order: first, all Ss were tested on the standard WGTA measure; secondly, all Ss were tested on the PBC measure; and finally, all Ss were tested on the shock avoidance measure. The procedures used for each of those situations are described below.

In the WGTA food competition measure of dominance, following shaping of food retrieval and familiarization in the apparatus, the test procedure was:

1. Both Ss were placed in the apparatus, alternating which $\underline{\mathbf{S}}$ was placed in the apparatus first throughout the trials.

2. A period of one minute elapsed before the initiation of the first trial.

3. One piece of food was placed on the sliding tray, and the tray was pushed up to the plexiglas partition.

4. The plexiglas partition was raised, and the food was available to the Ss.

5. When one of the Ss removed the food, the response was recorded, the delivery tray was pulled back, and the plexiglas partition was lowered ending the trial.

Ten trials per pairing were recorded with Ss paired within groups and between groups III and IV. Within group pairings consisted of forming all combinations of pairs within a particular group. Between group pairings consisted of forming all possible pairs between the two groups such that no pair contained two members of the same group. An individual group member was not tested more than twice in succession.

In the PBC food competition measure of dominance, following shaping of food retrieval and familiarization in the food competition apparatus, the procedure was: 
1. Both Ss were placed in the apparatus cages opposite of each other, with $\underline{S}_{1}$ placed in side 1 and $\underline{S}_{2}$ placed in second in side 2 every other pairing. The order of cage entry and cage side for individual $\underline{S_{s}}$ was alternated between pairings.

2. A period of one minute elapsed before the first trial.

3. The food delivery tray was pushed between the two cages.

4. After 10 seconds the plexiglas partitions were raised allowing the food the be removed.

5. When one of the $\underline{S}_{s}$ removed the food, the response was recorded, the delivery tray was removed, and the two plexiglas partitions were lowered.

Ten trials per pairing were recorded with $\underline{S}$ paired within groups and between groups III and IV. The with in and between group pairing procedure was identical to that of the WGTA test situation.

In the shock avoidance measure of dominance, following shaping, all animals were paired in all possible combinations within groups and between groups III and IV for two trial per day for five days per pairing for a total of ten trials per pairing. All $\underline{S}$ were tested by the same step by step procedure as follows:

1. Equipment and lights were turned on .

2. The center guillotine door was closed, and both the end doors were opened.

3. $\underline{S}_{1}$ and $\underline{S}_{2}$ were placed in the start box from two different transportation carriers; ${ }_{-}$was placed in first every other trial.

4. The start box door was closed, and one of the transport carriers (the goal box) was placed on the platform at the opposite end of the shuttle box from the Ss.

5. Ss were left in the start box for one minute before the beginning of the 
trial. During the entire time a white house light was on projecting light indirectly from the floor and lighting up the entire test chamber.

6. After one minute the green light came on and flashed for 3 seconds as a warning signal that the trial was starting.

7. Following the 3 second green flashing light, a constant red light came on, and the green light went off. At this point the center guillotine door opened, and the $\underline{S_{s}}$ could leave the start box.

8. The red light stayed on for 8 seconds. During this time one of the $\underline{S_{s}}$ could go into the goal box.

9. After the first $\underline{\mathbf{S}}$ went into the goal box, the door to this box was closed automatically not allowing the second $\underline{S}$ into the goal box.

10. After the 8 seconds of red light, the avoidance time, the red light went off, and the shock came on. During the shcok period the floor of the start box was electrified for 1 second, and then the floor of the opposite side of the shuttle box was electrified for 1 second.

11. The $\underline{S}$ in the goal box received no shock thus avoiding the shock by getting into the goal box first.

12. Following the shock the second $\underline{S}$ was removed from the shuttle box with the second transport carrier which was placed in the position of the goal box.

Shock thresholds were measured by observation of each animal in the start box side of the shuttle box using scrambled shock applied under remote control of E. For each individual $\underline{S}$ the intensity of the electrical shock was varied up to a maximum level defined as resulting in a definite and intense body movement response to the shock, generally a hard body jolt, retraction of all limbs, or an attempt to escape by leaping up. By decreasing and increasing the intensity of the shock a response level to the shock was determined for each $\underline{S}$ and is listed 
on Table 3. The response level was defined as consisting of a clear movement of $\underline{S}$ to shock generally a limb retraction, jump, or bite at the floor bars. If the shock intensity was increasing, the response level was listed as the point where these responses first occurred and if the shock intensity was decreasing the response level was listed as the point where these responses last occurred. The average of these two shock intensities was used as the response shock level. The average of these two listings being the final response level prior to shaping. During individual shaping of the avoidance response the response level was used and in some cases adjustments of increasing the level was necessary. The response levels for each $\underline{S}$ in Table 3 consist of the final and functional shock level used as the basis for the shock avoidance competition. The shock level used for each pair during shock avoidance competition was the average of the response levels of the Ss of that particular pair.

Certain pairings were not made with the older groups of subjects (groups I and II) so that injury was avoided to the individual Ss. All pairings were made in the Parallel Box since individuals did not come in direct physical contact and could not inflict injury on one another. Groups I and II were not tested between groups on the WGTA or on the avoidance test situation. Animal 3508 of groupll could not be paired with animals 5754 and 5755 (both of group II also) on either the WGTA or the avoidance test situations due to the immediate and vicious fighting behavior occurring when the animals were placed in the same box. 


\section{Chapter 3}

\section{RESULTS}

There were no significant correlations between body weight and dominance ranking within groups on any of the three measures. Stability of the dominance measurements was evaluated by correlating the first five trials with the last five trials of each pairing. The $t$-scores and correlations of these stability tests were as follows: avoidance competition -- $r=.95, t=12.6$, and df=16; Parallel Box competition - r $r=.95, t=12.16$, and df=16; and WGTA competition - $r=.96$, $t=12.92$, and $d f=16$.

Sex differences were significant $(t=2.4, p<.05)$ only on the avoidance test situation when all the groups' scores were combined into male or female groups. Females were on the average more successful in avoidance competition than males across groups $(\bar{X}$ males $=9.4$ and $\bar{X}$ females -22.2$)$. Combining the scores for groups III and IV into male and female groups for each testing procedure resulted in the following statistics: WGTA competition --- $\bar{X}$ males $=25.3, \bar{X}$ females $=16.8, d f=6, t=.86$, and $p<.5 ;$ avoidance competition $--\bar{X}$ males $=$ I1.0, $\bar{x}$ females $=25.4, d f=6, t=1.77$, and $p \quad .25$; and Parallel Box competition $--\bar{X}$ males $=28.3, \bar{X}$ females $=15.0, d f=6, t=1.61$, and $p<.25$. The above demonstrates that sex as an independent variable had no significant effect between groups III and IV within any of the three competition measures.

Correlations between test situations are summarized in Table 4. Overall correlations were as follows: WGTA correlated with the Parallel Box --- $r=.95$, $t=11.58$, and $d f=16(p<.01)$; WGTA correlated with avoidance --- $r=.26, t=1.07$, and $d f=16(p<0.5)$; Parallel Box correlated with avoidance $-m-r=.15, t=.60$, and $d f=16(p<0.8)$. 
Table 4

Correlations Between Tests

\begin{tabular}{|c|c|c|c|}
\hline Groups & $\begin{array}{l}\text { WGTA with } \\
\text { Parallel }\end{array}$ & $\begin{array}{l}\text { WGTA with } \\
\text { Avoidance }\end{array}$ & $\begin{array}{l}\text { Parallel with } \\
\text { Avoidance }\end{array}$ \\
\hline $\begin{array}{c}\text { Group } 1 \\
\vdots\end{array}$ & $\begin{array}{l}r=.94 \\
T=5.66^{*} \\
d f=4\end{array}$ & $\begin{array}{l}r=.37 \\
T=.80 \\
d f=4\end{array}$ & $\begin{array}{l}r=.20 \\
T=.40 \\
d f=4\end{array}$ \\
\hline Group II & $\begin{array}{l}r=.80 \\
T=1.88 \\
d f=2\end{array}$ & $r=1.0$ & $\begin{array}{l}r=.80 \\
T=1.88 \\
d f=2\end{array}$ \\
\hline Group III & $r=1.0$ & $\begin{array}{l}r=-.40 \\
T=.617 \\
d f=2\end{array}$ & $\begin{array}{l}r=-.40 \\
T=.617 \\
d f=2\end{array}$ \\
\hline Group IV & $r=1.0$ & $\begin{array}{l}r=-.80 \\
T=1.88 \\
d f=2\end{array}$ & $\begin{array}{l}r=-.80 \\
T=1.88 \\
d f=2\end{array}$ \\
\hline $\begin{array}{l}\text { Across } \\
\text { Groups }\end{array}$ & $\begin{array}{l}r=.95 \\
T=11.58^{*} \\
d f=16\end{array}$ & $\begin{array}{l}r=.26 \\
T=1.07 \\
d f=16\end{array}$ & $\begin{array}{l}r=.15 \\
T=.60 \\
d f=16\end{array}$ \\
\hline
\end{tabular}


Comparing low protein group III with high protein group IV on between group competition on the three measures of dominance yielded the results given in Table 5 and summarized below. WGTA competition between groups III and IV showed the low protein group III obtaining a significantly higher number of successful competitions with $t=4.65, d f=6$ and $p<.01$. PBC competition between groups III and IV showed the low protein group III obtaining a higher number of successful competition with $t=2.16, d f=4$, and $p<.07$ (the t-test used in this case only, allowed for nonhomogeneous variances, see Winer, 1971). Opposite results were found with avoidance competition between groups III and IV with the high protein group obtaining more successful competitions with $t=1.69, d f=6$, and $p<.08$. Within group ranking, sex and mean weights for all $\underline{S}$ tested on all three measurement techniques are given in Table 6. 
Table 5

t-Tests Between Groups III and IV on

Three Measures of Dominance

\begin{tabular}{llll}
\hline \hline Groups & WGTA & Parallel Box & Avoidance \\
\hline Group III & $\bar{X}=31$ & $\bar{X}=27.75$ & $\bar{X}=13.25$ \\
Group IV & $\bar{X}=9$ & $\bar{X}=12.25$ & $\bar{X}=26.75$ \\
Gcores & $t=4.7$ & $t=2.16 *$ & $t=1.69$ \\
& $\begin{array}{l}t f=6 \\
\text { t-Sc.01 }\end{array}$ & $\begin{array}{l}d f=4 \\
\end{array}<.07$ & $\mathrm{df}=6$ \\
& & $p<.08$ \\
\hline
\end{tabular}

* Used t-test allowing for non-homogenious variance (Winer, 1971) for this t-test only. 
Table 6

Within Group Ranking on Three Measures of Dominance

\begin{tabular}{|c|c|c|c|c|c|}
\hline $\begin{array}{l}\text { Animal } \\
\text { and } \\
\text { Group }\end{array}$ & Sex & $\begin{array}{c}\bar{X} \\
\text { weight } \\
\text { in } \\
\text { Grams * }\end{array}$ & $\begin{array}{l}\text { Rank on WGTA } \\
\text { Competition }\end{array}$ & $\begin{array}{l}\text { Rank on Parallel } \\
\text { Box Competition }\end{array}$ & $\begin{array}{l}\text { Rank on } \\
\text { Avoidance } \\
\text { Competition }\end{array}$ \\
\hline
\end{tabular}

Group I, Low Protein

$\begin{array}{rlllll}5 & f & 2495 & 3 & 3 & 2 \\ 6 & \text { m } & 2132 & 6 & 5 & 6 \\ 5766 & f & 2153 & 5 & 6 & 3 \\ 5872 & f & 2817 & 2 & 2 & 1 \\ 5976 & f & 2838 & 4 & 4 & 4 \\ 5979 & f & 2404 & 1 & 1 & 5\end{array}$

Grou II, High Protein

$\begin{array}{llllll}5754 & m & 6483 & 2^{* *} & 2 & 2^{* *} \\ 5755 & m & 7136 & 4^{* *} & 3 & 4^{* *} \\ 5756 & f & 4917 & 3^{* *} & 4 & 3^{* *} \\ 3508 & m & 6949 & 1^{* *} & 1 & 1^{* *}\end{array}$

Group III, Low Protein

$\begin{array}{rrrrll}8 & m & 2414 & 1 & 1 & 2 \\ 9 & f & 2392 & 2 & 2 & 4 \\ 10 & f & 1683 & 4 & 4 & 1 \\ 13 & m & 2081 & 3 & 3 & 3\end{array}$

Group IV, High Protein

$\begin{array}{lllllll}15 & f & 3182 & 3 & 3 & & 3 \\ 16 & f & 3138 & 2 & 2 & & 2 \\ 17 & f & 2459 & 4 & 4 & & 1 \\ 18 & m & 3101 & 1 & 1 & \ddots & 4\end{array}$

*Average weight of the individual Ss during the testing period. ** Since all pairings were not possible, ranking was based on $X \%$ successed for this group and only on the above designated tests. 


\section{Chapter 4}

\section{DISCUSSION}

The high correlations found between WGTA food competition and Parallel Box competition for food indicate that both techniques produce similar dominance rankings. Based on the evidence from the two appetitive measures of competition, the group data demonstrate that low protein (protein deprived) rhesus are more dominant than high protein rhesus supporting hypothesis I. In confirming hypothesis II, the results showed that high protein rhesus are more dominant than low protein rhesus on a nonappetitive competition situation, in this case shock avoidance competition. A summary of these findings would be that more low protein rhesus succeed in obtaining food than do high protein rhesus in a competitive situation. Yet, these same animals show a reversal when the incentive is changed from food to avoidance of shock. These findings coincide with Warren and Maroney's (1958) conclusions that changes in competition result from changes in the quality of the incentive instead of the quantity of the incentive.

Nowlis (1942) found that when subordinates were deprived and the dominant animal was not deprived that subordinates increased in food competition. The evidence would suggest that the high protein animals that were on deprivation would out perform the low protein animals that were not deprived of their normal daily diet allotments. However, this result was not found since even though the high protein animals were deprived, they were still out performed by the low protein rhesus on food competition.

Considered with Warren and Maroney's (1958) findings on quality of incentive, the above results would indicate that depriving a rhesus of protein increases the incentive value for food in general (since the food rewards used in this study 
were of low protein content) so that the low protein rhesus will out compete a high protein rhesus in the two appetitive competition situations of this study. The fact that this increased incentive value only affects the food competition situations and not shock avoidance competition points out the selective attention effect that protein deprivation has on the performance of rhesus macaques.

Adding to the significance of these findings, Angermeier's et al. (1968) statement that dominance over another did not occur if an animal was 1000 grams less in weight than a second animal, should be considered. The average weight for the low protein group III is 2142.5 grams, whereas the average weight for the high protein group IV is $\mathbf{2 9 6 5}$ grams giving the high protein animals an average weight advantage of 822.5 grams. Number 10 and 13 of the low protein group III are over 1000 grams less in weight than the high protein $\mathbf{S}$ numbers 15, 16, and 18 . Yet, on food competition the low protein group III significantly out performed (successfully retrieved more food) the high protein group IV which would seem to contradict Angermeier's et al. (1968) conclusion and again reinforce the concept that protein deprivation of the rhesus macaque increases the incentive value of food above that of high protein animals.

The shock intensity levels used in the shock avoidance competition (see Table 3) show that the low protein rhesus has a lower shock response level than the high protein rhesus. Since in testing between groups III and IV the average response shock level between the individuals being tested was used, then the low protein animal, in most cases, was tested under a shock intensity higher than his response shock level; whereas the high protein rhesus was tested at a level lower than his response shock level.

This situation would lead to speculation that the low protein animals were under greater motivation than the high protein animals with whom they were 
paired in the sthock avoidance competition. Yet, the high protein animals out performed the low protein animals on the shock avoidance competition situation. Observation of the animals during testing demonstrated that the low protein animals were not freezing to the increased intensity. However, the start box behavior patterns between groups were noticeably different.

The low protein rhesus typically adopted a stereotyped pacing pattern which coincided with being in front of the door when the eight second period terminated and the door was opened. In comparison the behavior pattern of the high protein animals was such that the animal went first to the door and attempted to open it, and then waited directly in front of the door as close as possible to it. Thus, when the high protein rhesus was placed with the low protein rhesus, the high protein animal was in front of the door when it opened blocking out the low protein animal. The usual amount of threats and appeasement gestures took place throughout the testing period.

Correlations within groups between shock avoidance competition and the two appetitive measures of competition were not as straight forward in terms of interpretation as the correlations between the two appetitive measures alone. For the low protein animals the correlations between appetitive and nonappetitive competition were low as would be expected given that hypothesis I and II were confirmed. However, with the high protein animals the correlations between appetitive and nonappetitive competition were high although not significant in all cases. The older high protein group of animals demonstrated a high positive correlation between appetitive and nonappetitive competition thus indicating that both appetitive and nonappetitive competition were indices of the same or similar phenomena of dominance for older high protein rhesus macaques. However, for the younger high protein group there were rather high 
negative correlations between the nonappetitive and appetitive measures of competition. These high negative correlations would indicate that the avoidance competition was actually measuring subordinance (the lower ranking animal being the more successful) instead of dominance in the younger high protein rhesus macaques. What could possibly be happening is that the more dominant animal was placing himself closer to the aversive "dangerous" stimulus and allowing the subordinate to escape to safer ground.

In field observations, such as those of Cayo Santiago by Altmann (1962), the younger adults and older juvenile rhesus macaques are found peripheral to the group. They are found in a position in which they can function as a buffer zone between outside danger and the vulnerable members of the inner circle of the group, namely pregnant and lactating females. The older adult males and females are found closer to the center of the group in most cases. Hall and DeVore (1962) and Hall (1960) found a parallel situation in Papio ursinus baboons where the subadult males are always on the perimeter of the group. When the baboon troop is moving the subadult males are found out in front of the main part of the group and are always the first to come upon unexpected or at least unseen dangers.

The actual experimental situation of shock avoidance competition apparently delineated between older and younger age groups of rhesus. Investigations of competition situations which do not use food should be attempted to further clarify this situation. Reasons for this difference between the two age groups of high protein animals can only be determined by further experimentation with nonappetive competition.

An interesting and supportive factor in favor of hypothesis III, in addition to the above information, is that all three measures of competition were stable measures as indicated in the results section. Also, there were no indications of 
warm-up periods for individual animals on the three measures, and furthermore, there was no tapering off of responding or waning of incentive value for the dominant (successful) animal .

In regard to the confounding effects that the variable of sex of the animals within each group could have upon the outcome of the dominance testing, it was shown in the results section that sex was a significant independent variable when all the groups' scores were combined into male or female groups. Since only groups III and IV were compared on between group dominance testing, then sex would have to be a significant independent variable between those two groups when they were combined into male and female scoring groups. However, when this combining was done there were no significant effects between the sexes for groups III and IV on any of the measurement techniques.

This finding would indicate that sex as an independent variable did not affect the outcome of the competition results of the between groups measure of groups III and IV on any of the three measurement techniques. Any effect that the sex of the group members of any group had on within group testing is irrelavant to the interpretation of the experimental outcome. However, inspection of the data gives no indication that within group testing was affected by the sex of the group members.

The results of the present experiment point toward further investigation along two lines of interest. First, since food competition does discriminate between groups of low and high protein rhesus indicating that the low protein animal is more aggressive when food is used as an incentive, then the values of the food incentive should be manipulated. Also, the deprivation level of the high protein animal should be varied in an effort to approximate the motivational level at which the low protein animals are operating. Secondly, a social 
competition situation is needed to compare with the food competition situation for both the low and high protein animals. The use of a manipulative incentive similar to Schusterman's (1964) may provide an interesting distinction between low and high protein rhesus macaques in regard to their social relationships and incentive values. 


\section{Chapter 5}

\section{SUMMARY}

Dominance behavior of rhesus macaques on either low or high protein diets was measured using three competition techniques. The appetitive measures consisted of food competition in the WGTA and food competition in a Parallel Box apparatus. The nonappetitive measure consisted of shock avoidance competition. The results indicated that rhesus monkeys raised on low protein diets were rated more dominant than those raised on high protein diets on food competition and that high protein rhesus monkeys. were more dominant on avoidance competition. All three measurement techniques were found to be stable, and the two appetitive measures correlated highly. 


\section{REFERENCES}

Almann, S. A field study of the sociobiology of rhesus monkeys, Macaca mulatta. Annals of the New York Academy of Sciences., 1962, 102, 338-435.

Angermeier, W. F., \& Phelps, J. B. Dominance in monkeys: Behavior and biochemistry. United States Air Force, Aeromedical Research Laboratory, Technical Report, 1967, No. 67-24, V, 13 p. (Psychological Abstracts 42: 7028)

Angermeier, W. F., Phelps, J. B., Murray, S., \& Reynolds, H. H. Dominance in monkeys: Early rearing and home environment. Psychonomic Sciences, $1967, \underline{9}(7 B), 433-434$.

Angermeier, W. $F_{0}$, Phelps, J. B., Oreste, M., Davis, H., \& Reynolds, H. A. Dominance hierarchies in monkeys. Psychonomic Science, 1967, 9(7B), 435-436.

Angermeier, W. F., Phelps, J. B., Murray, S., \& Howansteine, J. Dominance in monkeys: Sex differences. Psychonomic Science., 1968, 12, 344.

Bernstein, 1. S. Stability of the status hierarchy in a pigtail monkey group (Macaca nemestrina). Animal Behaviour, 1969, 17, 452-458.

Biernoff, A., Leary, R. Wo, \& Littman, R. A. Dominance behavior of paired primates in two settings. Journal of Abnormal and Social Psychology, $1964,68(1), 109-113$.

Boelkins, C.R. Determination of dominance hierarchies in monkeys. Psychonomic Science, 1967, $2,317-318$.

Carpenter, C. R. Societies of monkeys and apes. In C. H. Southwick (Ed.), Primate social behavior. New York: Litton Educational Publishing, Inc., 1963. Pp. 24-51.

Carpenter, $C . R$. Tentative generalizations on the grouping behavior of non-human 
primates. In C. R. Carpenter (Ed.), Naturalistic behavior of nonhuman primates. University Park, Pennsylvania: The Pennsylvania State University Press, 1964. Pp. 392-397.

Ginsberg, W., \& Allee, W. C。 Some effects of conditioning on social dominance and subordination in inbred strains of mice. Physiological Zoology, 1942, 15, 485-506.

Hall, K. R. L。 Social vigilance behaviour in the chacma baboon, Papio ursinus. Behaviour, 1960, 16, 261-294.

Hall, K. R. L. and DeVore, I. Baboon social behavior. In Irven DeVore (Ed.), Primate behavior. New York: Rinehart and Winston, Inc , 1965, Pp. 53110 .

Hamilton, C. L. Comparison of two methods of dominance testing in the monkey. Psychological Reports, 1960, 6, 247-250。

Koford, C. B. Group relations in an island colony of rhesus monkeys. In C. H. Southwick (Ed。), Primate social behavior. New York: Litton Educational Publishing, Inc., 1963. Pp. 136-152.

Koyama, N. On dominance rank and kinship of a wild Japanese monkey troop in Arashiyama。Primates, 1967, 8(3), 189-216. (Psychological Abstracts 43: 2323)

Leary, R. W., \& Maroney, R. J. The effects of home-cage environment on the social dominance of monkeys. Journal of Comparative and Physiological Psychology, 1962, 55, 256-259.

Locke, K。D., Locke, E。 A。, Morgan, G. A., \& Zimmermann, R. R。 Dimensions of social interactions among infant rhesus monkeys. Psychological Reports, $1964,15,339-349$.

Locke, K. D.; Morgan, G. A. Jro, \& Zimmermann, R. R。 Method for observing 
social interactions in groups of infant rhesus monkeys. Psychological Reports, 1964, 14, 83-91.

Maroney, R., \& Leary, R. A failur to condition submission in monkeys. Psychological Reports, 1957, 3, 472.

Maroney, R. J., Warren, J. M., \& Sinha, M. M. Stability of social dominance hierarchies in monkeys (Macaca mulatta). Journal of Social Psychology, 50, 285-293.

Maslow, A. H. The role of dominance in the social and sexual behavior of infrahuman primates: IV. The determination of hierarchy in pairs and in a group. Journal of Genetic Psychology, 1936, 49, 161-198.

Maslow, $A_{0} H_{0}, \&$ Flanzbaum, S. The role of dominance in the social and sexual behavior of infrahuman primates: II. An experimental determination of the behavior syndrome of dominance. Journal of Genetic Psychology, 1936, 48, 278-309。

Masserman, J. H., Wechkin, S., \& Woolf, M. Social relationships and aggression in rhesus monkeys. Archives of General Psychiatry, 1968, 18, 210-213.

Mason, W. A. The effects of social restriction on the behavior of rhesus monkeys:

1. Free social behavior. Journal of Comparative and Physiological Psychology, 1960, 53, 582-589.

Mason, W. A. The effects of social restriction on the behavior of rhesus monkeys: III. Dominance tests. Journal of Comparative and Physiological Psychology, $1961,54,694-699$.

Meyer, D. R., Treichler, F. R., and Meyer, P. M. Discrete-trial training techniques and stimulus variables. In Schrier, Harlow, and Stollnitz (Eds.), Behavior of nonhuman primates, modern research trends. New York: Academic Press, 1965, Pp. 1-49. 
Miller, R. E., Murphy, J. V., \& Mirsky, I. A. The modification of social dominance in a group of monkeys by interanimal conditioning. Journal of Comparative and Physiological Psychology, 1955, 48, 392-396.

Miller, R. E., \& Murphy, J. V. Social interaction of rhesus monkeys: I. Foodgetting dominance as a dependent variable. Journal of Social Psychology, 1956, 44, 249-255.

Miller, R. E., \& Banks, J. H. Jr. The determination of social dominance in monkeys by a competitive avoidance method. Journal of Comparative and Physiological Psychology, 1962, 55, 137-141。

Murphy, J. V., \& Miller, R. E. The manipulation of dominance in monkeys with conditioned fear. Journal of Abnormal and Social Psychology, 1956, 53, 244-248.

Nowlis, V. The relation of degree of hunger to competitive interaction in chimpanzee. Journal of Comparative Psychology, 1941; 32, 91-115.

Nowlis, V. Sexual status and degree of hunger in chimpanzee competitive interactions. Journal of Comparative Psychology, 1942, 34, 185-194.

Plotnik, R., King, F. A., \& Roberts, L. Effects of competition on the aggressive behavior of squirrel and cebus monkeys. Behaviour, 1968, 32, 315-332.

Schusterman, R. J. The effect of a manipulatory incentive on social interactions of rhesus monkeys. Animal Behavior, 1964, 12, 416-419.

Sparks, Jo Allogrooming in primates: A review. In D. Morris (Ed.), Primate ethology. Garden City, N. Y.: Doubleday \& Company, Inc., 1969. Pp. 190-225.

Van Hooff, J. A. R. A. M. Facial expressions in higher primates. In J. Napier \& N. A. Barnical (Eds.), Symposia of the Zoological Society of London, number 10, the primates. London: The Zoological Society of London, 
1962. Pp. 103-104.

Van Hooff, J. A. R. A. M. The facial displays of the Catarrhine monkeys and apes. In D. Morris (Ed.), Primate ethology. Garden City, N. Y.: Doubleday \& Company, Inc., 1969. Pp. 9-88.

Warren, J. M., \& Maroney, R. J. Competitive social interaction between monkeys. Journal of Social Psychology, 1958, 48, 223-233.

Wickler, W. Socio-sexual signals and their intra-specific imitation among primates. In D. Morris (Ed.), Primate ethology. Garden City, N. Y.: Doubleday \& Company, Inc., 1969. Pp. 89-189.

Winer, B. J. Statistical principles in experimental design. (2nd ed.) New York: McGraw-Hill, 1971. 